\title{
DIVINE SILENCE:
}

\section{THE SIGNIFICANCE OF STRUCTURE IN GENESIS 12}

\author{
Jordan Pickering \\ George Whitefield College, Cape Town
}

\begin{abstract}
Genesis 12 is a crucial chapter in biblical theology, with most scholarly attention being given to the promises given at the start. Structurally, however, the chapter should be viewed as a unit, and its emphasis falls on v.10. This article aims to demonstrate that the text is best viewed as a series of five speech-response pairs, with the central 'pair' emphatically omitting any speech. The absence of speech in v.10 is an interpretive key, identifying the theme of testing as central to this episode, and placing the promises made to Abram in their proper context: the gifts and blessings of God are ultimately less important than being in properly ordered relationship with the Giver.
\end{abstract}

Key Words: Blessing; Promises; Structure; Testing; Trust

In the study of Genesis 12 , most attention is given to the promises that occupy the first three verses. This is understandable seeing that these promises form the basis of divinehuman relationship in the rest of Scripture such that the Apostle Paul identifies them as the same promises to which the Christian church is heir. Moreover, in Genesis these promises are framed as God's direct response to the pronouncements of curse that litter the eleven preceding chapters, which identifies God's relationship with Abram as central to the plan to undo the ruinous effects of the Fall in Genesis 3. Such critical verses deservedly occupy our attention.

Nevertheless, God's promises to Abram are given in a narrative context - a context that is too easily neglected in favour of the more illustrious verses that open the chapter. More than this, the narrative context in question contains the account of Abram's aimless wanderings around Canaan, and his eventual exit into Egypt in the south that sees him passing off his wife as his sister. Given that there are two more wife-as-sister stories in Genesis in which a Patriarch's wife is nearly married off to the king of the land, the rest of Genesis 12 can be a source of bewilderment or even embarrassment.

While it would be convenient to be able to dismiss the more unusual content of this chapter as unrelated to the important material at the beginning, careful inspection of the chapter as a whole suggests that it ought to be considered a unit.

\section{Extent}

The central argument of this paper is that Genesis 12 is a carefully planned whole. However, in studies of Genesis 12 the dominant tendency has been to divide the chapter into two, with an almost unchallenged consensus that 12:10-20 represents an independent episode. The question of extent - i.e. the start and end point of the episode under consideration - can therefore be resolved only by the end of this paper. So, for now we shall make only provisional comments. 
The starting point of the episode is not uniformly agreed upon. Commentators vary as to whether they treat 11:27-32 together with 12:1-9 or separately from it.

In favour of its inclusion, Genesis 11:27-32 introduces Abram to us, as well as setting up the predicament that pursues this family for eleven more chapters: death and (for the first time in Genesis) barrenness threatens Terah's family line. This is a problem that the promises given to Abram in chapter 12 address indirectly.

Against its inclusion, chapter 11 ends with the death of Abram's father, even though the chronology given in the text would suggest that Abram departed for Canaan several decades before Terah died. The report of his death therefore is rhetorical, not chronological, and serves as closure of the episode (Arnold, 2009:129).

Chapter 11 certainly provides context against which the promises in chapter 12 must be understood, but it seems clear that 12:1 represents the start of a new episode.

\section{Possible Divisions within Chapter 12}

How may chapter 12 be divided further? The promises given in vv.1-3 rightly occupy significant attention, but their importance should not be seen as an argument that they are separable from the narrative in which they are set. This narrative can, however, seem disjointed. For example, source critics generally agree that the text of 12:1-9 is not derived from a unitary source, seeing vv.4b-5 as an insertion of $\mathrm{P}$ material into $\mathrm{J}$ (Westermann, 1995:146). ${ }^{1}$ Genesis $12: 4$ certainly pauses the narrative in order to comment upon Abram's age when he left Haran for Canaan, and this pause could be seen as a structural divider, but given that the destination promised in v.1 is identified in v.7, it would seem that there is intended continuity. Westermann (1995:145) also argues that detaching vv.1-3 from their context serves to drain vv.6-9 of meaning; 'it is the whole text that requires attention'.

It is reasonable to divide the text at v.9 because v.10 seems to shift attention away from Abram's travel itinerary and onto the famine as a new and significant event. Verse 10 also begins with וַיר: ('it came to be') - a word commonly used to mark a transition in narrative. Thus most scholars argue for vv.1-9 as a unit (so Arnold, Fretheim, Hamilton, Noth, Westermann etc.). ${ }^{2}$

As convincing as this reasoning is, I believe that the reasons for treating the whole chapter as a structural unit are better.

\section{Structure}

It is beyond question that chapter 12 observes a division at v.10. The question is whether this division begins a new episode or merely subdivides a larger episode. This question may at first seem inconsequential, but as we shall see in due course, there is much at stake. Let us examine some of the reasons why chapter 12 should be treated as a unit.

Firstly, v.9 does not provide closure to Abram's travel itinerary but demands continuation. The Hebrew text of v.9 includes three travelling words, two of which are infinitive absolute. This construction is emphatic about the ongoing nature of Abram's

Towner (2001:133) places a division here, seemingly for these source-critical reasons, but otherwise observes the usual break after v.9, and treats vv.10-20 as a unit.

2 Cotter (2003:84) places the division after v.8, but apart from being harder to justify from the grammar this is just a minor tweak of the same two-fold division supported by the others, and he makes nothing more of it. 
travels. ${ }^{3} \mathrm{He}$ is shown the land but he is not yet given rest. The new thing introduced by in v.10 is significant, but the travel narrative is unresolved by v.9. He journeys on.

Secondly, at either end of chapter 12 there is a command for Abram to 'Go!' In v.1, God gives the command for Abram to go to Canaan, and this same command is reiterated in the mouth of Pharaoh in v.19.

This repetition would seem to indicate a relationship between the start of the chapter and its end. There are two structural devices common in Hebrew texts that are characterised by this kind of repetition. The first is known as inclusio, in which the author uses repetition of a story element at the beginning and end of a unit to indicate its extent. The second is known as concentric or pivot structure, in which the author pairs story elements in concentric layers around a focal point called the pivot (which would therefore also result in repetition of the first and last elements).

Given the Hebrew preference for these devices, it is overwhelmingly likely that the commands to 'Go!' in vv.1-3 and vv.19-20 are not coincidental, but intended to function as 'book-ends' for a single episode.

\section{How Genesis 12 is Structured}

If chapter 12 has been conceived as a unit, what clues does the narrator give as to the internal structure of the episode?

Yairah Amit (2001:49ff) has helpfully catalogued the most common structural devices in Hebrew narratives, including structures based on plot development, such as pediment structure, and structures based on scene change, in which the story develops around movement in setting or character.

In Genesis 12 there are continual shifts in location, which would suggest a scenic structure: God first addresses Abram in Haran, then in Canaan; after these divine encounters, Abram moves to the Negev, and then to Egypt. However, in conjunction with these changes in location, there is another feature that seems more significant still: each movement is precipitated by a speech.

In his analysis of the structure of vv.10-20, Westermann (1995:164) suggests that the scholars Koch and Gunkel had made too little of the 'opening and closing dialogues' as structurally significant. Westermann has correctly noted the importance of these speeches but has himself underplayed the structural significance of all the speech events in this chapter, not just those in vv.10-20. Each of these speech events signals a shift in the story and elicits a response, but there is no two-way dialogue; we are never allowed to hear what the characters think of what is said. We may only observe and evaluate their response. This unusual patterning of the text suggests that it has been divided into scenic units, each containing a speech and a response.

The identification of this device may help to account for the notable silences in the text. According to Westermann (1995:164), for example, Hermann Gunkel believed that the absence of an explanation for how the pharaoh discovered that Abram was the reason for the curse is so glaring that it must have dropped out of the text of this chapter. Yet if Genesis 12 has been structured according to a series of speeches and responses, then it is

See for example Wenham, 1987:267. 
entirely likely that the author has intentionally avoided unnecessary complications to this pattern, especially those that may require two-way dialogue. ${ }^{4}$

There are four overt sections that follow a speech-and-response pattern: God speaks and Abram responds in the first two; in the latter two, Abram and then Pharaoh are the speakers. However, there is one scene at a critical moment at the centre of the chapter in which a response is not preceded by a speech. Verse 10 describes the onset of a drought and Abram's actions in response, but there is no speech involved.

Leaving this complication aside for the moment, I argue that the scenic divisions are as follows:

A 'Go!' (1-6)

$$
\begin{gathered}
\text { B Entering Canaan (7-9) } \\
\text { C Famine (10) } \\
\text { B Entering Egypt (11-17) }
\end{gathered}
$$

A' 'Go!' (18-20)

In addition to being divided according to speech-response scenes, I regard this as an example of pivot structure, with concentric layers around a central focal point. If valid, the key moment in the text is indeed the absence of speech prior to Abram's response to the famine. Pivot structures are often 'in the eye of the beholder', 5 and so I leave the strength of this suggestion to the reader's judgement.

The more important matter is whether or not the passage is divided scenically in this way. Of course, it is apparent that the central event in this structural analysis (v.10) diverges from the expected pattern of speech and response. But even more so than rules, patterns are made to be broken. They establish expectation: the author introduces patterns so that the reader is able to detect order; but the author breaks patterns so that - in the subversion of expectation - the reader is able to detect emphasis. The lack of a speech event in v.10 leaves us with two options. Either this is evidence of a poor fit of this passage to the proposed structure, or the divergence is calculated and intentional, and thus essential to proper understanding of this chapter. Exegesis of the text may be able to establish which option is the case.

4 This silence is all the more necessary if the chapter is utilizing a pivot structure, as I suggest below, because the author must control both the number of scenes and their symmetry. The detective work that led to Abram's condemnation would have to be ignored if there were no mirror image of this scene in the first half of the chapter.

5 Some commentators have loose definitions of what constitutes an intentional pivot structure, and as such see them all over the text. Christensen (2001:1xxxiv-lxxxvii) bases his reading of Deuteronomy on the idea that the book is not only full of pivots, but the smaller pivot structures combine to form larger ones; his definition of pivot structure is not necessarily too loose, but he certainly considers them to be numerous. By contrast, Nathan Klaus' book (1999) on pivot structure in the Former Prophets defines them so rigidly that he sees almost none. 


\section{Analysis}

We will focus attention on the first half of the passage, as it has the primary responsibility for establishing reader expectation.

\section{'Go!' (1-6)}

${ }_{1}$ And YHWH said to Abram, 'Go by yourself from your land and your relatives and from the house of your father to the land that I will show you. ${ }_{2}$ And I will make 6 you into a great nation, and I will bless you, and I will make your name great; and you must be a blessing, ${ }_{3}^{7}$ and I will bless those who bless you and he who dishonours ${ }^{8}$ you I will curse, and in you all the families of the earth will find blessing. ${ }^{9}$

${ }_{4}$ And Abram went as YHWH had spoken to him and Lot went with him. Now Abram was seventy-five years old when he left Haran. ${ }_{5}$ And Abram took Sarai his wife, and Lot the son of his brother, and all his property that he had accumulated, and the persons that he had acquired in Haran. And they departed in order to go to the land of Canaan, and they arrived in the land of Canaan. ${ }_{6}$ And Abram passed through the land until the (sacred) site of Shechem until the terebinth of Moreh; ${ }^{10}$ at that time the Canaanites were in the land.

The first speech event of the episode is the momentous one in which God addresses Abram with His intention to bless. The following elements feature most strongly in the episode as a whole:

\section{- Divine-human Relationship in the Promises}

Although these blessings are often thought of as unconditional, there is nevertheless an important obligation required of Abram if these blessings are to be true of Him, namely, the obligation to obey the command to 'Go!'.

Wenham (1987:275) points out that grammatically, the command to 'Go' is strong, whereas all the promises to bless are expressions of intentionality and subordinate to the initial command. This serves to emphasise the importance of the initial command and the contingency of the blessings upon it.

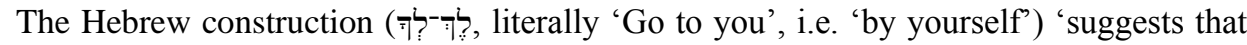
the person mentioned is going alone and breaking away from the group' (Wenham, 1987:266). The emphasis is not merely upon going (something presumably easy for a people accustomed to nomadic life), but also upon leaving behind.

6 Baden (2010:226) argues on the basis of syntax that God is making an invitation - it is a proposal rather than a list of promises. The sense of a request for partnership seems to me to be too weak, nullifying the sense of command that begins the chapter and the sense that God is also sovereign over his own will - He brings about whatever He wishes. I favour Wenham's analysis (1987:266) that the cohorts express that the thing promised 'is to be expected with certainty'. It is God's determined will to bless.

Cf. Baden, 2010:228f, 233.

8 Mitchell (1987:93) argues that קלל 'has the broadest range of meaning of all the curse words, and its meaning completely overlaps the meanings of the other words'. This indicates that any sort of curse is sufficient to warrant God's severe response. Hence I have followed the ESV in translating קלל with 'dishonour', which does not capture its breadth but functions as the lower limit, implying actions of greater severity too.

9 Interpreting this verb with the sense of 'finding blessing' is supported also by Towner (2001:135).

10 Sarna (1989:91) points out that is is a combination of words used only here. It is probably not that this is the future site of Shechem, but rather he argues that it has a special meaning of 'sacred site'. 
Dislocation from one's land and relatives did not imply merely 'starting fresh' or 'finding a new home', but rather an invitation to belong to new systems and structures. Abram's call is not merely an invitation to relocate. The call to leave one's family implies the formation of a new one. ${ }^{11}$ There is no overt description in Genesis 12 of the relationship into which Abram was being brought, but leaving his 'father's house' would imply that it is familial and not just religious. It is the forsaking of one family structure in order to form another.

Abram is required to separate himself from a three-fold network of relationships. He is to 'go by himself' away from his land, his relatives, and his father's house. The scope narrows from the broadest sphere of self-identification, his nation, to the smallest, his family unit; complete dissociation is demanded. God is clearly not opposed to family ties per se; Sarai, his orphaned nephew Lot, and the servants - all those under his headship are extracted from the previous structure and go with Abram. ${ }^{12}$ But what Abram must forsake is the sense of to whom he belongs. Naturally, this demanded trust: Abram is required to set aside the support structure and the belonging that he has, and to trade it for a miraculous future to be provided by what may have been to him an unknown God.

Verse 1 also hereby indicates that the blessings offered in the covenant were not exactly unconditional. Receiving them depended upon Abram's trust in God's ability to bring about what was promised, placing himself under God's 'fatherhood', and it depended on his obedience to the call to leave and follow. Abram's subsequent actions - building altars to YHWH in Canaan - indicate that he understood his call to be a radical commitment to follow YHWH as his God.

Consequently, there are early hints that there is a relational element to the promises, and it is certainly fair to infer a condition of obedience to YHWH as a fundamental part of them. ${ }^{13}$ Mathews sums up:

No obligations are placed upon Abram to maintain the promises... he must only respond

to the Lord's command to 'leave,' an act of loyalty (2005:106).

So, obedience, trust, and loyalty are all implications of the command to leave behind family entanglements.

\section{- Land in the Promises}

The contingency of the blessings upon the initial command also places the land in an interesting position. Much is made of the gift of land to Abram, especially as it is an aspect

11 It arguably bears conceptual similarities to the marriage language in Genesis 2:24 ('Therefore a man shall leave his father and his mother and hold fast to his wife').

12 Cotter (2003:90f) views Lot's presence with Abram as an act of disobedience - Abram's inability to dissociate fully and obey God completely. This is an interesting suggestion as it accounts for the repetitive interest in Lot (his presence is mentioned in v.4 and v.5), but it does not account for the narrator's statement in v.4 of Abram's compliance (“Abram went just as YHWH had said...”). By contrast, Arnold (2009:133) sees Lot's presence as a commendation of Abram's virtue, because he was 'fulfilling his patriarchal duty to his deceased brother by providing for the orphaned nephew' - a much better fit of the evidence, although it remains a puzzle that Lot was not considered to be a candidate as heir. Perhaps Lot's presencehas more to do with the thematic interest in Genesis in those who were so close to inheritance of the promises and yet fell short (e.g. Terah, Ishmael, Esau).

13 This places the promises in Chapter 12 in significant continuity with its more overtly conditional restatement in Chapter 17. The relational sphere of operation of the covenant is evident in the relational formula ('I will be your God and the God of your descendants after you') that is emphasised in several major restatements of covenant, e.g. Genesis 17:7-8; Exodus 6:7; Deuteronomy 29:10-13; Jeremiah 31:31-34; Revelation 21:3. 
of the promises that is repeated and elaborated upon on a regular basis in Genesis. Genesis makes reference to the promises 47 times, only 7 of which do not mention the land explicitly; 29 refer exclusively to it (Wright, 2004:78). It is such a dominant element that it comes as something of a surprise to note that the gift of the land is not among the promises made to Abram in 12:1-3.

The absence of overt mention of the land is surprising, but it is nevertheless implicit in these verses. Abram is commanded to go to the land that God will bless. The land itself is not here one of the blessings, but rather the place in which blessing is given.

The centrality of land to the promises is also implicit in the first of them in v.2. God promises that He will make of Abram 'a great nation (גili)'. Unike is a political concept and requires a territorial base (Speiser, 1964:86), which would have implied to Abram that God intended to grant him a place. Only upon arrival, in 12:7, does God show him the land and make it explicit that it is to be given to his descendants.

So the land is crucial as the environment in which the promises will flourish.

\section{- The Nations and the Promises}

The promises themselves all centre on blessing, for Abram himself, for those associated with him, and indeed for all nations. Hamilton (1990:373f) notes that YHWH's promises are given in seven clauses; the verb in the central clause shifts to imperative, which marks it out syntactically as pivotal in some sense. This clause is the command to 'be a blessing', which moves the focus from Abram as recipient and emphasizes his role as agent of blessing. Similarly, Hamilton adds that the seventh clause - if as is likely it has passive force - also emphasizes the need to be a blessing, this time specifying the clans of the earth as beneficiaries. This suggests that international blessing is something of a 'final goal' of these promises. In answer to the worldwide curses of Genesis 1-11, Abram is to be the source of blessing.

While those favourably related to Abram experience blessing, the counterpoint to these promises is the threat of curse upon those who dishonour God's people. The text promises, in Hebrew אָרָ, which Sarna (1989:89) defines as, 'to place under a ban, to deprive of the benefits of divine providence,' as retribution upon any who pִ pִurse, dishonour) Abram. This is a particular comfort to someone recently called to forsake his family supportstructures and to follow nomadic wanderings in a foreign land. Sarna adds that as an alien in Canaan without legal protection, Abram would be in 'particular need of God's providential care'. ${ }^{14}$

Given that blessing and curse are here made dependent on the nations' relationship with Abram, it is surely not accidental that the second half of this chapter has as its theme Abram as an agent of curse upon Egypt.

In summary, God's promises require Abram to leave behind his past structures of identity and social security, and in its place to display trust and obedience in YHWH as the new author of his identity. The promises are contingent upon his entry into a land that God will identify, which becomes the environment in which blessing will be given, and in turn Abram is to be an agent of blessing, even to the whole world.

14 Ibid. 


\section{- Response}

Vv.4-6 record Abram's response to God's call. It is unambiguous: in response to the

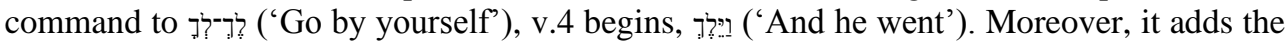
verification, 'as YHWH had spoken', emphasising Abram's full compliance.

According to v.6, he journeys as far as Shechem and the terebinth of Moreh. This tree was obviously noteworthy enough to serve as a landmark, and almost certainly had spiritual significance to the Canaanites (Sarna, 1989:91). Canaanite religious associations with trees were such that Deuteronomy 16:21 would eventually prohibit Israel from planting them in the vicinity of the altar.

So, this verse indicates that Abram has travelled to a region that was home to two spiritually important Canaanite religious landmarks: this terebinth and the sacred site of Shechem. The intention behind the inclusion of references to Canaanite landmarks is almost certainly to characterise the land and its inhabitants as idolatrous (the Canaanites themselves are mentioned here for otherwise-obscure reasons). ${ }^{15}$ Abram has been given a land that is not only occupied, but also devoted to gods other than the one who called him.

\section{Entering Canaan (7-9)}

${ }_{7}$ And YHWH appeared to Abram and he said, 'To your seed I will give this land.' And he built there an altar to YHWH - the one who appeared to him. ${ }_{8}$ And he moved on from there to the hill country on the east of Bethel, and pitched his tent with Bethel on the west and Ai on the east. He built there an altar to YHWH, and he called on the name of YHWH. ${ }_{9}$ And Abram journeyed on journeying to the Negev.

In the second speech event God is again the speaker, establishing Him as the director of the events so far. He says to Abram, 'To your seed I will give this land,' confirming Abram's arrival in the place upon which blessing will be focused.

\section{- Response}

In that potentially hostile place, in the heartland of Canaanitic religion, Abram builds the first altar to YHWH, staking God's claim to that ground.

Wenham (1987:266f) notes that some interpreters seek to distance Abram's altarbuilding from any reference to Canaanite religion for fear that it may make Abram seem to be recognising Canaanite 'holy ground'. Such concern seems unnecessary. Abram's altarbuilding here of all places, in the midst of Canaanite holy places and while the Canaanites were in the land, is to be understood as an act of courage and fidelity. Abram has been called into a covenant relationship with YHWH, he has been promised this land, and thus in faith he plants YHWH's standard in the midst of the Canaanite worship centre. As such,

15 Source critics are predisposed to look for compositional history of a text, and thus tend to account for this statement about the Canaanites as indicative of a later viewpoint. For example, Westermann (1995:154) says, 'Only a narrator who wants to indicate the remoteness of the patriarchal period can write in this way' (cf. Fretheim, 1994:424). This neglects to explain why such narrative distance would be necessary. At no point would an Israelite reader be in any doubt that 'Father Abraham' was entering non-Israelite Canaan. The mention of Canaanite occupation surely must serve another function in the story than to indicate that "this happened in the far distant past, long before the Israelite tribes migrated into Canaan" (Westermann, ibid); a fact self-evident to a later reader. It seems rather more likely - as more recent commentators recognize (e.g. Cotter, 2003:91) - that the narrator is reminding his reader that the land is inhabited, and presumably that the Canaanites are an immediate threat. 
minimising references to Canaanite religion obscures Abram's radical trust in God's promises, which seems to be the clear point of the story so far.

Having marked this as the first point of entry into God's land of promise, Abram resumes his travels south until he eventually traverses the entire land and reaches the Negev. Verse 9 emphasises the on-going nature of Abram's journeying. He has not yet found rest. The promises are still future: although the land has been given to Abram's seed, he is not given leave to settle, but remains an alien in the land of promise.

This brings us to the centre point of this episode: the speech event with no speech.

\section{Famine (10)}

${ }_{10}$ Now there arose a famine in the land, and so Abram went down to Egypt in order to sojourn there because the famine in the land was severe.

In v.10, the narrator announces a famine. It is clearly a new scene, but there is no speech from God nor any other character. There is merely response to it: Abram takes his family into Egypt. Is the lack of a speech event significant, or it is rather evidence of mis-analysis of the structure of this episode?

In terms of the reader's expectation, the silence is a surprise. God has been directing events until this point. More than this, He directed Abram to this land and identified it as the place in which blessing and security would be provided. Abram would be justified in requiring some sort of divine explanation. He has fulfilled his obligation to go and to leave behind; more than this, he has behaved with exemplary boldness and faithfulness to YHWH. At such a crucial time, a word from the Lord would be appropriate.

So we expect a speech, but it does not come from YHWH. The fact that it also doesn't come from Abram is additionally important. In this speech-response format (in all four of the complete pairs in this passage) there is no dialogue. The recipient of the speech is always a silent respondent. Abram's silent response seems, therefore, to further heighten the absence of a divine word to precipitate it.

The internal evidence in this episode points to expectation raised and subverted. The reader is conditioned to expect God to tell Abram what to do next, only for the narrator to play upon its absence. However, the most compelling confirmation that this is a speechresponse event without a speech is supplied by the narrator in a later episode.

Genesis 26 tells a parallel story from the life of Isaac. It shares with Genesis 12 the Patriarch's worry that the inhabitants of the land will be a danger to him and his family, and it shares the strategy of attempting to pass off his wife as his sister. Crucially, it also shares famine as a catalyst for the Patriarch's migration, and Genesis 26:1 even makes otherwiseunnecessary reference to the famine from Abram's day, ${ }^{16}$ inviting comparison and contrast. In that story, God does provide the expected caution and instructions, which shows that drought in the Promised Land was an anomaly that demanded explanation. This was true most of all for Abram who had no precedent for it and no history with YHWH. The story is crying out for a speech that might direct his response, yet God is surprisingly silent.

16 It says, 'Now there was a famine in the land, besides the former famine that was in the days of Abraham.' Given that the first famine was well before Isaac was even born, there is no possibility of confusion of the two famines, and therefore no reason for disambiguation. The reference to Abram's famine is almost certainly a means of calling the older story to mind for the purposes of comparison. 
The famine presented an immediate challenge to the promises that Abram had received, and the absence of explanation or instruction therefore marks this out as the first test of Abram's trust in God to do what He has said. Without requesting or receiving guidance, he elects rather to seek refuge in Egypt and to secure the blessings in his own way.

\section{Entering Egypt (11-17)}

In view of God's silence, the third complete speech-response pair casts Abram as speaker; he assumes the role of director of affairs.

The land had yielded the curse of famine instead of the blessing that was promised, and this prompts Abram to take control. As the couple nears Egypt, he hatches a plan to ensure his own safety and well-being. This was an understandable concern, because as someone separated from his kinsmen, he was without protection and at the mercy of his hosts.

Hamilton (1990:380) wonders why Abram felt vulnerable in Egypt but not in Canaan, speculating that it may have something to do with some moral failing particular to the Egyptians - perhaps that they were reputed to steal wives, or that they were lacking in a law of hospitality. There is no puzzle at all if we are correct that the famine and God's silence had caused Abram's trust to falter. In Canaan Abram was still certain that YHWH would keep his promises, including the promise to curse Abram's opponents severely; the flight to Egypt is seemingly an active expression of doubt that YHWH is able to keep his word. ${ }^{17}$ Abram's fear of the Egyptians comes into direct contrast with God's promise to bless him and to curse his enemies. In other words, the lack of security that Abram felt on account of being without kinsmen had in fact been directly addressed by God's promise to provide him with protection.

Abram's plan was to call his wife his sister, which allowed her to be a bargaining chip and allowed him to be someone whom his hosts would favour. He could thus avoid being seen as an obstacle to anyone's hopes of marriage with Sarai, and he could benefit from their attentions long enough to see out the famine and make his escape home. His scheming was successful up to a point, but leads to a further predicament. His wife was noticed by the Pharaoh, which made any attempt to delay the marriage impossible.

In spite of Abram's doubt in God's ability to bless and curse outside of the borders of Canaan, God nevertheless lives up to His promises. Although Pharaoh did not know Sarai was married, the secret is known to God and marrying her still counts as dishonour to God's covenant people. Being faithful to His promises and His threats, God curses the house of Pharaoh.

\section{'Go!' (18-20)}

The final speech-response pair sees Abram reprise his role as the silent recipient of commands. This time it is not God who is directing his path to the Promised Land, but Pharaoh, and Abram is exposed as the bringer of curse to the nations, not the source of blessing that he should have been.

As in 12:5, Abram 'takes and goes' to Canaan. In v.5, it was a departure with family and possessions, trusting the word of God. In v.20, it is a departure with an armed escort at

17 It is possible that Abram retains trust in YHWH's promises, but merely doubts that they still apply when not in the Promised Land. Yet even so his flight would call into question his trust in God's ability to bless him in the land in spite of drought, and thus this seems like a less coherent explanation. 
the command of Pharaoh. Whether or not there is an implied criticism of Abram in this chapter for never consulting YHWH in his trials is unclear. But one way or another, the man who has not yet fully obeyed the command of God will now be compelled to obey the word of Pharaoh. Indeed, he leaves with greater possessions, but after a failure to believe what God had promised.

\section{Significance}

Bill Arnold (2009:137) includes in his commentary on vv.10-20 a list of 'confusing features for which we have no satisfying answers.' Two of these remain outside of the interests of this article, namely that there are similar wife-sister episodes repeated elsewhere, and that we are asked to believe that Sarai at age 65 was desirable to the Pharaoh. ${ }^{18}$ The three other 'confusing features' are addressed more directly by this structural analysis, namely:

- Sarai colludes without objection

- Abram is supposedly righteous but uses his wife to save himself

- The acquisition of wealth in this way is not condemned

If our structural analysis is correct, Sarai's silence is explained by the choice of narrative device: none of the characters are given a voice to respond to the speech of each section. Sarai's silence does not imply collusion - she may have protested, but Abram is employing weighty manipulation that would be hard to defy. Either way, these silences all act as an invitation for us as readers to evaluate the various responses and learn from them what to emulate or avoid.

The lack of explicit judgment concerning Abram's use of his wife and his questionable acquisition of wealth is also no longer a serious puzzle, because once the structure identifies the famine as a test of faith, it becomes clear that Abram's response falls short. Though God had promised to preserve and prosper Abram in the land, Abram succumbs to fear and makes foolish plans of his own to secure the same ends, yet with unplanned undesirable consequences. Though God commissioned Abram to be a blessing to the nations, Abram becomes a curse to Egypt.

It is not necessary for the text to supply overt condemnation of Abram's plans for safety and prosperity; the structure of the text suggests a verdict for us. Theologically, the speechStart here response units place the following themes in parallel:

A (1-6) Abram must be a blessing to the nations

B (7-9) Abram exhibits courageous acts of faith in Canaan

C (10) Testing of personal faith in what was promised

B` (11-17) Abram exhibits acts of cowardice and unfaith in Egypt

A (18-20) Abram brings curse to the nations

At the heart of this passage is an examination of whether or not God's family will believe what has been promised in spite of trying circumstances. Abram cannot yet answer in the

18 Perhaps it is merely that the pharaoh might himself have been old? Given the ages to which people were reputed to live in these stories, perhaps middle-aged Sarai was an attractive, age-appropriate choice for Pharaoh and powerful patriarchs such such as he? 
affirmative, and attempts therefore to secure shalom in his own way and outside of the environment of relationship with YHWH. This vacillation will be a regular pattern with Abram $^{19}$ until it is finally resolved in Genesis 22. As a result, his own plans in v.13 achieve success - v.16 confirms as much - but at the cost of dishonour of his wife and curse upon the nations he ought to be blessing. The condemnation of Abram is implicit but clear.

\section{The importance of testing}

Verse 10 is a pivotal moment. It is set up as a test of the scope and genuineness of Abram's trust in YHWH. The silence of God was a cruel withdrawal of the privileged relationship that God had condescended to give Abram up to that point, and the withdrawal of blessing from the land placed an obstacle directly in the path of fulfilment of God's promises. Why does this apparent cruelty occupy the centre of a passage usually famed for God's free gift of blessing?

The test demonstrates God's priorities inherent in the promises of blessing. The Accuser could level against Abram the same accusations later made against Job: Abram trusts because the material benefits make it worth his while. The relationship is presently beneficial; without the benefits would there still be a relationship?

The call of Abram is a pronouncement of blessing as an antidote to the curse that litters Genesis 3-11. Its aim is not mere material benefit but the restoration of divine-human relationship. These are not trivial matters. If Abram (and his later 'seed') prizes the gifts without regard for the Giver, it would be merely to repeat the perversion of Eden. Relationship with YHWH must be the prize, not the blessings that attend Him. Abram started well - and on some level may have thought he deserved God's favour - but promises of blessing are in no way mechanical. Trust in God needs to survive trial, and belief in God's word needs to survive absence of explanation and even Heaven's silence.

The structure of Genesis 12 is crucial, because it magnifies the focus upon the silence of v.10. It demands that we read God's promises with the reminder that faith must be deeprooted in a relationship of radical trust in the Giver of promises, even when He appears most absent. What matters is not that He speaks, but that He has spoken.

\section{BIBLIOGRAPHY}

Amit, Y, 2001. Reading biblical narratives: literary criticism and the Hebrew Bible. Minneapolis, MN: Fortress Press.

Arnold, BT, 2009. Genesis. The New Cambridge Bible Commentary.

New York: Cambridge University Press.

Baden, J, 2010. The morpho-syntax of Genesis 12:1-3. The Catholic Biblical Quarterly, 72(2):223-237.

Christensen, D, 2001. Deuteronomy 1:1-21:9. 2nd ed. (Word Bible Commentaries).

Nashville, TN: Thomas Nelson.

Cotter, DW, 2003. Genesis. (Berit Olam). Collegeville, MN: Liturgical Press.

19 So, for example, his attempt to fulfil the promise of a child by taking Hagar. 
Fretheim, TE, 1994. The book of Genesis: Introduction, commentary and reflections.

In: LE Keck, ed. New Interpreter's Bible. Nashville, TN: Abingdon Press.

Hamilton, VP, 1990. The book of Genesis chapters 1-17. (NICOT).

Grand Rapids, MI: Eerdmans.

Klaus, N, 1999. Pivot patterns in the Former Prophets.

Sheffield: Sheffield Academic Press.

Mathews, K, 2005. Genesis 11:27-50:26 (NAC). Nashville, TN: Broadman \& Holman.

Mitchell, CW, 1987. The meaning of ברד 'to bless' in the Old Testament. Atlanta, GA: Scholars Press.

Sarna, N, 1989. The JPS Torah commentary: Genesis. Philadelphia, PA: Jewish Publication Society.

Speiser, E, 1964. Genesis (Anchor Bible). Garden City, NY: Doubleday.

Towner, WS, 2001. Genesis. (Westminster Bible Companion). Louisville, KY: Westminster John Knox Press.

Wenham, G, 1987. Genesis 1-15 (Word Bible Commentaries). Waco, TX: Word Books.

Westermann, C, 1995. Genesis 12-36. A Continental commentary. Minneapolis, $\mathrm{MN}$ : Fortress Press.

Wright, C, 2004. Old Testament ethics for the people of God. Leicester: IVP. 